\title{
Effect of socioeconomic status on infectious diarrhea in Egyptian children
}

\author{
Yossuef Nadra Sayed ${ }^{1}$, Abou Zekri Maha El- Sayed ${ }^{2}$, Salem Amany Abd El-Fattah, ${ }^{3, *}$ \\ ${ }^{1}$ Experimental Kitchen Research Unit, Food Technology Research Institute, ARC, Giza, Egypt \\ ${ }^{2}$ Consltant Paediatrician Gastroenterology and Nutrition Specialized, Children Hospital, Cairo University, Egypt \\ ${ }^{3}$ Special Food and Nutrition Department, Food Technology Research Institute, ARC, Giza, Egypt
}

Email address:

Amanysalem2013@gmail.com (S. A. Abd El-Fattah)

\section{To cite this article:}

Yossuef Nadra Sayed, Abou Zekri Maha El- Sayed, Salem Amany Abd El-Fattah. Effect of Socioeconomic Status on Infectious Diarrhea in Egyptian Children. International Journal of Nutrition and Food Sciences. Vol. 3, No. 6, 2014, pp. 519-525.

doi: $10.11648 / j . i j n f s .20140306 .15$

\begin{abstract}
Infectious diarrhea is a common health problem among Egyptian infants and young children. It leads to high indicate of morbidly and mortality. The present study aimed to evaluate the effect of socioeconomic status of the children, affected with diarrhea, on their diseases. Two hundred and ninety children suffering from diarrhea attending the outpatient clinic of Cairo University Children Hospital (Abul-Reech) during the summer time from May to August 2013 were enrolled in the study. A designed questionnaire sheet including some social parameters e.g. parents' education, number of family members, feeding of the children were used. Nutritional status of patients enrolled were assessed by measuring their anthropometric measurements and compared to Growth Charts [1]. The results indicated that the majority of mothers were illiterate. Most of children enrolled were aged $7-24$ months, so they were receiving weaning foods with breastfeeding. The results also revealed that most of children had 6-10 motions/day and their stool were watery or watery with mucous. The majority of children had BMI normal percentiles. The results showed that a negative correlation between mother's education and both number of family and diarrhea duration $(\mathrm{p} \leq 0.05)$. Also, there were a positive correlation between water sources and child's homeland ( $\mathrm{p} \leq 0.01)$. A negative correlation was found between water sources and fever $(\mathrm{p} \leq 0.05)$. Conclusion: These findings suggested that mother's education, number of family members, sanitary water supply are crucial factories in affection of our children with infectious diarrhea diseases. Recommendation: The previous findings have important implications on policy for health intervention, and support the view that investing in female education may have substantial benefits on the child health. Also, reducing diarrhea dangers involves providing better water sources and sanitation for the entire population and hygiene of the person caring of the child.
\end{abstract}

Keywords: Diarrheal, Young Children, Sociological Parameters, Anthropometric Measurements

\section{Introduction}

In developing countries, diarrheal diseases, as a group, remain the leading cause of illness and the second leading cause of death among young children, particularly during the first two years of their lives. Diarrheal diseases accounted for $11 \%$ of the estimated 7.6 million under-five deaths, globally, [2].

Worldwide, diarrheal diseases considered to be one of the major causes of mortality among under 5 years of children, accounting for million child deaths despite all progress in its management. In Egypt, deaths among children under 5 years due to diarrheal diseases accounted to $3 \%$ of all causes of death. Although it might kill millions in the developing countries, it considered to be a problem in the developed countries as well [3]. Guidelines for the management of diarrheal illnesses have been refined, and new strategies for prevention and control of this major health problem have also been developed [4].

Diarrheal diseases are leading cause of preventable death, especially among children under five years in developing countries. Diarrhea is defined as a child with loose or watery stool for three or more times during a 24-hour's period. The frequency and severity of diarrhea is aggravated by lack of access to sufficient clean water and sanitary disposal of human waste, inadequate feeding practices and hand washing; 
poor housing conditions and lack of access to adequate and affordable health care [5].

Studies have been conducted in the past to establish risk factors of diarrhea. A study conducted in Egypt showed that some socio-demographic characteristics like maternal age and child's age are some determinant factors for the occurrence of episode of diarrheal disease [6].

El-Zanaty and Way [7] reported that, Egyptian Demographic and Health Survey (2008, EDHS) diarrheal diseases for children in Egypt were 12.6\%, 18.6\% and 11.3\% of children less than 6 months, 6-11months and 12-23 months, respectively. Diarrheal episodes were common among children living in both Upper and Lower Egypt [7].

Infections that cause diarrhea are a major public health problem in developing countries and other places where resources are scarce, particularly in young children [8]. Gastrointestinal infections in children can significantly impact their families and society and result in increased medical expenditures, lost productivity, childcare and pain and suffering [9].

Knowledge about the direct and indirect costs of acute diarrhea may provide the needed impetus for control of acute diarrhea in Egypt. It is therefore important to document these costs for formulating effective preventive health care policy.

The present study aimed to evaluate some of risk factors of diarrhea disease among infant children such as child's age, mother's age and her education and water sources.

\section{Subjects \& Methods}

\subsection{Subjects}

The present study was carried out from May to August 2013, 290 young children affected diarrhea were enrolled in the study. The patients were randomly selected from Cairo University Children Hospital (Abul-Reech), Cairo, Egypt.

The children were divided into three groups as following: group (1) children aged 3-6 months $(\mathrm{n}=60)$, group (2) children aged 7-12 months $(\mathrm{n}=144)$ and group (3) children aged 13-24 months $(n=86)$.

The data were collected by a personal interview with each mother's child to fill the specially designed questionnaire sheet, which included the following items:

A Personal and family data of the child including mother's age, father's age, family homeland, number of family members, and their education.

B Data related to the child disease such as, diarrhea duration, number of motions/ day, stool character, fever and dehydration.

C Feeding list of the child e. g.: breast feeding, weaning food, family food, breast +weaning food, breast feeding + family foods and weaning foods + family foods.

\subsection{Assessment of Nutritional Status of the Child}

Anthropometric measurements were taken by the same operator, according to conventional criteria and measuring procedures [10].

Body Weight $(\mathrm{Kg})$ for each child and Height $(\mathrm{cm})$ were measured to the nearest $100 \mathrm{~g}$ and $0.5 \mathrm{~cm}$ respectively.

Body Mass Index (BMI) was calculated using the following formula and compared to growth chart [1]:

$$
\mathrm{BMI}=\text { Body weight }(\mathrm{Kg}) / \text { Height }\left(\mathrm{m}^{2}\right) \text {. }
$$

Triceps and subscapular, skinfold thickness measurements were used to provide an estimate of total body fat [10] by Holtain LTD caliper. Skinfold thickness measurements were compared with the reference standards proposed by [11] and were expressed as a percentage of ideal value for sex and age at $50^{\text {th }}$ percentile. Head circumference $(\mathrm{Cm})$ and Mid-upper arm circumference $(\mathrm{Cm})$ were also measured [10].

\subsection{Statistical Analyses}

Statistical analyses were performed using SPSS Software version 19.0; SPSS, Chicago, IL. Descriptive statistics were present in frequency tables, mean, standard deviation and correlated between studied variables.

\section{Results and Discussion}

Diarrheal disease is a major cause of children death in the developing world. In developing countries a quarter of infant and childhood mortality is related to diarrhea [12]. Diarrhea creates huge burden on families of low income countries as Egypt. About $95 \%$ of the patients under study were less than five years old and those less than one year represent $39.6 \%$. This shows a strong tendency of diarrhea to occur among children less than 2 years of age [13].

The social status of the families might affect the health of the child as mother's age and mother's education. Therefore, one of the main objectives of the present study was focused on the assessment of social characteristics the find out its relation to infectious diarrhea in the children.

The data in table (1) showed that, majority of the children were females $(53.10 \%)$, about half of children were coming from urban areas $\left(46.7,54.2\right.$ and $48.8 \%$ for $1^{\text {st }}, 2^{\text {nd }}$ and $3^{\text {rd }}$ groups, respectively). The majority of families included 3 or 4 person, while, the minority of families included more than 6 person $\left(3.3,4.2\right.$ and $9.4 \%$ for $1^{\text {st }}, 2^{\text {nd }}$ and $3^{\text {rd }}$ groups, respectively). The results indicated that, the majority (more than two-third) of mother's aged 21-30 years (73.3, 75 and $69.8 \%$ for $1^{\text {st }}, 2^{\text {nd }}$ and $3^{\text {rd }}$ groups). Then, one - fifth of mother's age were (31-40) years $\left(20\right.$ and $20.9 \%$ for $1^{\text {st }}$ and $3^{\text {rd }}$ groups, respectively), but group 2 had $9.7 \%$ only in this age group.

The results indicated that, the majority of mothers in the three groups which were visiting the Abul-Reech Hospital are illiterate $\left(30,38.9\right.$ and $44.2 \%$ for $1^{\text {st }}$ and $3^{\text {rd }}$ groups, respectively). These results can by explain by that most of mothers were coming from rural areas where they did not educate the girls and married below 20 years. This result are lined with [14] who observed that majority of mothers were illiterate in Ethiopia. Wierzba et al., [15] who found a high 
percent of population in Benha and Abu-Homos, Egypt were studied was illiterate. Moreover, this finding is similar with the result obtained from another study in Ghana, Nigeria and
Ethiopia, where the prevalence of diarrhea varies according to mother's education which was relatively high among children of illiterate mothers [16, 17 and 14].

Table (1). Distribution of children according to some socioeconomic characteristics $(n=290)$

\begin{tabular}{|c|c|c|c|c|c|c|}
\hline \multirow{2}{*}{ Parameters } & \multicolumn{2}{|c|}{ Group $1(n=60)$} & \multicolumn{2}{|c|}{ Group $2(n=144)$} & \multicolumn{2}{|c|}{ Group $3(n=86)$} \\
\hline & No. & $\%$ & No. & $\%$ & No. & $\%$ \\
\hline \multicolumn{7}{|l|}{ Sex: } \\
\hline Boy & 20 & 33.3 & 68 & 47.2 & 48 & 55.8 \\
\hline Girl & 40 & 66.7 & 76 & 52.8 & 38 & 44.2 \\
\hline \multicolumn{7}{|l|}{ Baby's homeland: } \\
\hline Urban & 28 & 46.7 & 78 & 54.2 & 42 & 48.8 \\
\hline Rural & 32 & 53.3 & 66 & 45.8 & 44 & 51.2 \\
\hline 3-4 persona & 30 & 50 & 92 & 63.9 & 56 & 65.1 \\
\hline 5-6 person & 28 & 46.7 & 46 & 31.9 & 22 & 25.6 \\
\hline$\geq 7$ person & 2 & 3.3 & 6 & 4.2 & 8 & 9.4 \\
\hline \multicolumn{7}{|l|}{ Mother's age: } \\
\hline$\leq 20$ & 4 & 6.7 & 18 & 12.5 & 8 & 9.3 \\
\hline $21-30$ & 44 & 73.3 & 108 & 75 & 60 & 69.8 \\
\hline $31-40$ & 12 & 20 & 14 & 9.7 & 18 & 20.9 \\
\hline \multicolumn{7}{|l|}{ Mother's education: } \\
\hline Illiterate & 18 & 30 & 58 & 38.9 & 28 & 44.2 \\
\hline Primary level & 6 & 10 & 4 & 2.8 & -- & -- \\
\hline Preparatory level & 16 & 26.7 & 24 & 16.7 & 6 & 7 \\
\hline Secondary level & 14 & 23.3 & 48 & 33.3 & 34 & 39.5 \\
\hline Collage level & 6 & 10 & 12 & 8.3 & 8 & 9.3 \\
\hline \multicolumn{7}{|l|}{ Father's age: } \\
\hline $21-30$ & 26 & 43.3 & 58 & 40.3 & 32 & 37.21 \\
\hline $31-40$ & 26 & 43.3 & 76 & 52.7 & 48 & 55.81 \\
\hline $41-50$ & 8 & 13.4 & 10 & 7 & 6 & 6.98 \\
\hline \multicolumn{7}{|l|}{ Father's education: } \\
\hline Illiterate & 26 & 43.3 & 46 & 31.9 & 38 & 41.9 \\
\hline Primary level & 2 & 3.3 & 4 & 2.8 & 2 & 2.3 \\
\hline Preparatory level & 4 & 6.7 & 14 & 9.7 & 10 & 11.6 \\
\hline Secondary level & 24 & 40.0 & 70 & 48.6 & 28 & 32.6 \\
\hline Collage level & 4 & 6.7 & 10 & 6.9 & 10 & 11.6 \\
\hline Indoor running water (storage on the roof) & 6 & 10.0 & 28 & 19.4 & 20 & 23.3 \\
\hline Unprotects water (pump) & 14 & 23.3 & 32 & 22.2 & 20 & 23.3 \\
\hline
\end{tabular}

These results probably because education provides the knowledge of the rules of hygiene, feeding and weaning practices, and the interpretation of symptoms which enhances timely action on childhood illness. Data in the same table (1) resulted in the most of father's age were between 31-40 years and majority of fathers were illiterate ( 43.3 and $41.9 \%$ for groups 1 and 3, respectively). While, the majority of father's education in group 2 were secondary level (48.6\%). The results showed that the water source was indoor running water (tap water) in $66.67,58.33$ and $53.48 \%$ for $1^{\text {st }}, 2^{\text {nd }}$ and $3^{\text {rd }}$ groups, respectively. While, the minority of viewers had indoor running water (storage on the roof) which were 10 , 19.45 and $23.26 \%$ for $1^{\text {st }}, 2^{\text {nd }}$ and $3^{\text {rd }}$ groups, respectively. Nearly one-fourth of households 23.33, 22.22 and 23.26\% for $1^{\text {st }}, 2^{\text {nd }}$ and $3^{\text {rd }}$ groups, respectively used drinking water from unprotected sources (pump). These results almost similar with those [14] who found that about one-third of households used drinking water from unprotected sources (pump) in Ethiopia.

Table (2) shows that diarrhea duration was less than 5 days in most of the children $53.4,54.16$ and $46.4 \%$ for $1^{\text {st }}, 2^{\text {nd }}$ and $3^{\text {rd }}$ groups, respectively. The present study revealed that, most of the children had 1-5 times of motions/day for group $1^{\text {st }}(56.70 \%)$ which aged $\leq 6$ months. While, the children in groups 2 and 3 had 6- 10 of motions/day which accounted in 48.60 and $51.20 \%$. These results are agree with [13] who found that the mean of diarrhea motions were 8 motions/ day. The stool characteristics are shown in table (2). The results indicated that, majority of stool were watery $86.70,45.80$ and $32.6 \%$ for $1^{\text {st }}, 2^{\text {nd }}$ and $3^{\text {rd }}$ groups, respectively. Then, the watery with mucous were 26.40 and $23.30 \%$ for $2^{\text {nd }}$ and $3^{\text {rd }}$ groups, respectively. Fever were present in 53.3 and $58.33 \%$ of children in groups 1 and 2, respectively, while, in the third group the children were not suffering of fever (62.8\%). Most of the children were not dehydrated $93.3,84.7$ and $81.8 \%$ for $1^{\text {st }}, 2^{\text {nd }}$ and $3^{\text {rd }}$ group, respectively. These results are line with [15]. But, the obtained results were in opposite trend with those [13] who found that dehydration was almost present in $52.7 \%$ of cases. The present study showed that the children whose age between 6-23 months were at high risk of 
developing diarrhea when compared with children whose age less than five months. This was in line with study conducted in Ethiopia as reported by [14]. Ethiopian finding showed that children aged from 6-23 months are more endanger of diarrheal disease than other age groups. The possible explanation could be due to environmental exposure and increased introduction of solid foods which are unsafe and poor hygiene, while exclusive breastfed infants in the first 6 months of life are more safety.

\subsection{Health Status for Children}

Table (2). Distribution of children according to the health status during interview ( $n=290)$.

\begin{tabular}{|c|c|c|c|c|c|c|}
\hline \multirow{2}{*}{ Parameters } & \multicolumn{2}{|c|}{ Group $1(n=60)$} & \multicolumn{2}{|c|}{ Group $2(n=144)$} & \multicolumn{2}{|c|}{ Group $3(n=86)$} \\
\hline & No. & $\%$ & No. & $\%$ & No. & $\%$ \\
\hline \multicolumn{7}{|l|}{ Diarrheal duration: } \\
\hline$\leq 5$ days & 32 & 53.4 & 78 & 54.16 & 40 & 46.4 \\
\hline $6-10$ days & 14 & 23.3 & 44 & 30.56 & 20 & 23.3 \\
\hline $11-15$ days & 14 & 23.3 & 22 & 15.28 & 26 & 30.3 \\
\hline No. of motions/day 1-5 times: & 34 & 56.7 & 56 & 38.9 & 36 & 41.8 \\
\hline $11-15$ times & 2 & 3.3 & 918 & 12.5 & 4 & 4.7 \\
\hline 16-20 times & 2 & 3.3 & -- & -- & 2 & 2.3 \\
\hline \multicolumn{7}{|l|}{ Character of stool: } \\
\hline Watery & 52 & 86.7 & 66 & 45.8 & 28 & 32.6 \\
\hline Loose & 4 & 6.7 & 22 & 15.3 & 10 & 11.6 \\
\hline Semisolid & 4 & 6.7 & 4 & 2.8 & 6 & 7.0 \\
\hline Semisolid - mucous & -- & -- & 8 & 5.6 & 4 & 4.7 \\
\hline Loose - mucous & -- & -- & 2 & 1.4 & 6 & 7.0 \\
\hline Watery - mucous - blood & -- & -- & -- & -- & 4 & 4.7 \\
\hline Watery - loose - mucous & -- & -- & -- & -- & 2 & 2.3 \\
\hline Semisolid - blood & -- & -- & 2 & 1.4 & 2 & 2.3 \\
\hline Watery - blood & -- & -- & 2 & 1.4 & 4 & 4.7 \\
\hline \multicolumn{7}{|l|}{ Fever: } \\
\hline Yes & 32 & 53.3 & 84 & 58.3 & 32 & 37.2 \\
\hline No & 28 & 46.7 & 60 & 41.7 & 54 & 62.8 \\
\hline \multicolumn{7}{|l|}{ Dehydration } \\
\hline Yes & 4 & 6.7 & 22 & 15.3 & 16 & 18.6 \\
\hline No & 56 & 93.3 & 122 & 84.7 & 70 & 81.8 \\
\hline
\end{tabular}

\subsection{Children Feeding}

Table (3). Distribution of children according to the child's feed.

\begin{tabular}{|c|c|c|c|c|c|c|}
\hline \multirow{2}{*}{ Parameters } & \multicolumn{2}{|c|}{ Group $1(n=60)$} & \multicolumn{2}{|c|}{ Group $2(n=144)$} & \multicolumn{2}{|c|}{ Group $3(n=86)$} \\
\hline & No. & $\%$ & No. & $\%$ & No. & $\%$ \\
\hline Breast feeding & 40 & 66.7 & 56 & 38.9 & 14 & 16.3 \\
\hline Weaning food & 8 & 13.3 & 22 & 15.3 & 6 & 7 \\
\hline Family food & 2 & 3.3 & 4 & 2.8 & 40 & 46.5 \\
\hline Breast feeding + weaning food & 10 & 16.7 & 8 & 5.6 & 2 & 2.3 \\
\hline Breast feeding + family food & -- & -- & 48 & 33.3 & 20 & 23.3 \\
\hline
\end{tabular}

The collected data in table (3) shows that, the children aged $\leq 6$ were receiving exclusive breastfeeding $(66.7 \%)$, while $(16.7 \%)$ were receiving weaning food with breastfeeding. The second group aged (7-12) months 38.9\% were receiving exclusive breastfeeding, and $33.3 \%$ were receiving family foods with breastfeeding. The third group aged (13-24) months $46.5 \%$ were receiving family foods.

\subsection{Anthropometric Measurements}

The collected data in the table (4) shows the anthropometric measurements for children under study. The results indicated that the mean age of the children 4.85, 9.25 and 17.21 months for 1st, 2nd and 3rd groups. The mean of skin fold of children aged 13-24 months had less of skin fold compared to group 1 and 2. The means of BMI had 16.43, 16.84 and 16.11 for $1^{\text {st }}, 2^{\text {nd }}$ and $3^{\text {rd }}$ groups, respectively.

Figure (1 a) showed that the body mass index (BMI). The results indicated that the majority of children were between $2 \mathrm{SD}$ to $2 \mathrm{SD}$ when compared to growth chart [1] (70, 72.22 and $86.05 \%$ for 1 st, 2nd and 3rd groups, respectively). 
While the minorities of children were $\geq 2 \mathrm{SD}$ of growth chart [1] $30,27.78$ and $13.95 \%$ for the same groups, respectively.

Figure (1b) shows that the $20 \%$ of children were $51-100 \%$ of references standards for triceps skin fold thickness and $6.67 \%$ only were more than $100 \%$ in group 1 . On the other hand, the results indicated that the majority of children in groups 2 and 3 were $51-100 \%$ of references standards for triceps skin fold thickness (72.22 and $74.42 \%$, respectively), while, the minority of children in the same groups were more than $100 \%$ (9.72 and $4.65 \%$, respectively). These results may be due to the diarrhea episodes, quality of foods, sanitary water supply and mother's education. The skin fold test is not applicable to age $\leq 6$ months $(73.33 \%$ of group 1$)$ according to Lee and Nieman [11].

\subsection{Correlation Coefficient among Certain Variables}

A Correlation coefficient between some studied variable and health status

From the data in table (5), it could be seen that there were a positive correlation between the baby's homeland and water sources, between fever and dehydration and between weight and type of feeding $(\mathrm{p} \leq 0.01)$ for each, and between character of stool and type of feeding ( $\mathrm{p} \leq 0.05)$. Meanwhile, there are negative correlations between the fever and water sources $(p \leq 0.05)$. There were negative correlations between the mother's education and both number of family and diarrhea duration $(\mathrm{p} \leq 0.05)$ for each. Also, there were negative correlation between the dehydration and water sources $(\mathrm{p} \leq 0.01)$.

There were a positively significant correlations between age and each weight, character of stool and type of feeding $(\mathrm{p} \leq 0.01)$ for each. Moore et al., [18] reported that maternal education and early weaning were significant decrease risk factors for diarrhea duration. Positive correlated was found between age at weaning and diarrhea. Moreover, [19] examined the effects of access to water on the incidence of diarrhea in children. Their results showed access to piped water reduced the incidence of diarrhea, but the result is also related to families' income and education of mothers.

B Correlation coefficients between some studied variable and anthropometric measurements:

The statistical analysis reported in Table (6) showed that there were a significant correlation between the baby age and each of weight, height and head -circumference $(p \leq 0.01)$, between the weight and each height, head circumference, Mid-upper arm circumference, skin fold and body mass index $(p \leq 0.01)$ for each, between height and both head circumference and Mid-upper arm circumference $(\mathrm{p} \leq 0.01)$ for each, between age and Mid-upper arm circumference $(p \leq 0.05)$, and between head circumference and BMI $(p \leq 0.05)$ Meanwhile, there were advisable correlation between baby sex and each weight, height, head circumference and Midupper arm circumference $(\mathrm{p} \leq 0.01)$.
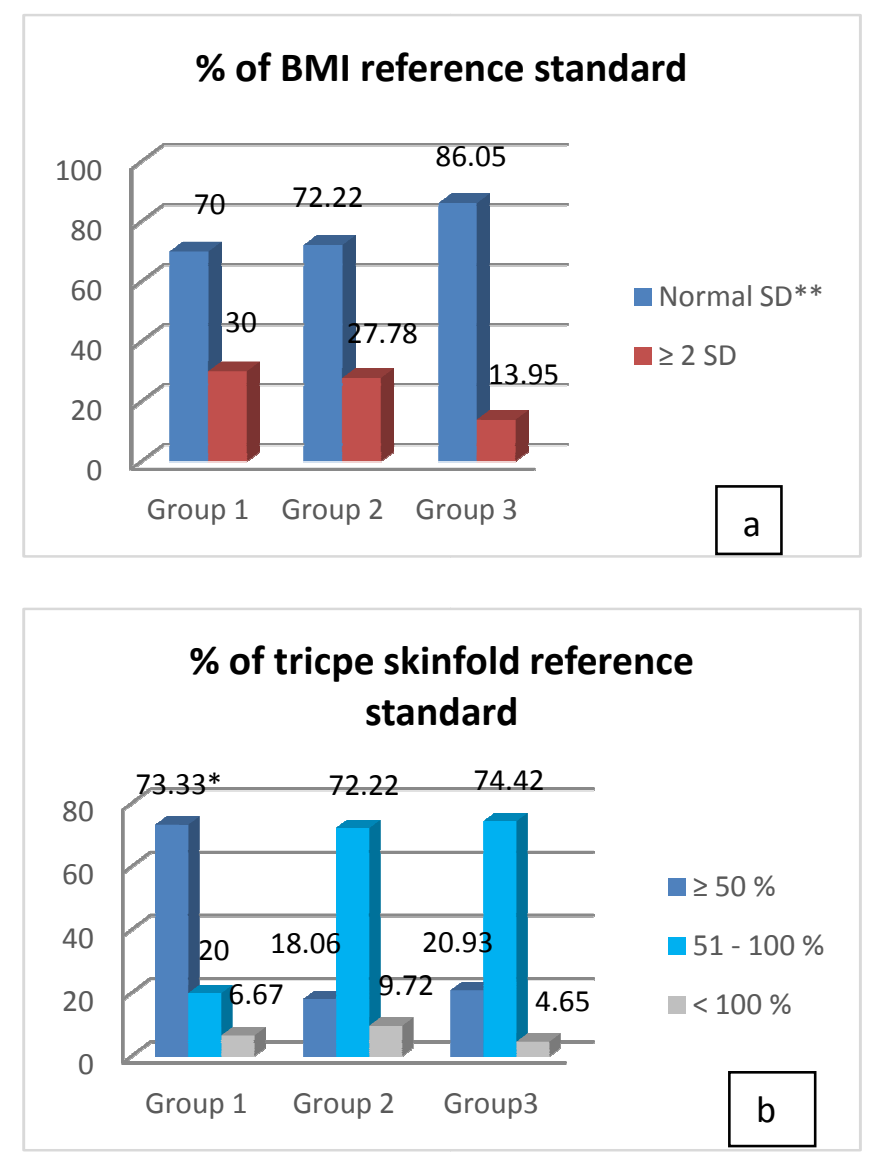

Fig (1). a) BMI: body mass index for children under study compared to Growth Chart by (WHO, 2007).B) Compared skinfold by the reference standards by (Lee and Nieman, 2003). * The children are less than 6 months. **-2 SD to $2 S D$.

Table (4). Anthropometric measurements for children (means $\pm S D$ ).

\begin{tabular}{llll}
\hline Parameters & Group 1 $(\mathbf{n}=\mathbf{6 0})$ & Group 2 $(\mathbf{n = 1 4 4})$ & Group 3 $(\mathbf{n}=\mathbf{8 6})$ \\
\hline Age (month) & $4.85 \pm 0.94$ & $9.25 \pm 1.85$ & $17.21 \pm 3.38$ \\
Weight $(\mathrm{Kg})$ & $5.98 \pm 1.31$ & $7.62 \pm 1.43$ & $9.15 \pm 1.52$ \\
Height $(\mathrm{Cm})$ & $60.11 \pm 4.28$ & $67.22 \pm 4.80$ & $75.29 \pm 6.13$ \\
Head circumference (Cm) & $39.12 \pm 5.67$ & $43.10 \pm 1.99$ & $45.85 \pm 2.31$ \\
Mid-upper arm circumference (Cm) & $11.35 \pm 2.07$ & $13.01 \pm 1.64$ & $13.36 \pm 1.57$ \\
Skin fold (mm) & $7.41 \pm 2.63$ & $7.59 \pm 2.78$ & $6.93 \pm 2.51$ \\
BMI (Body mass index) & $16.43 \pm 2.60$ & $16.84 \pm 2.45$ & $16.11 \pm 1.70$ \\
\hline
\end{tabular}


Table (5). Correlation coefficient between some studied variable and health status $(n=290$ child)

\begin{tabular}{|c|c|c|c|c|c|c|c|c|c|c|c|c|}
\hline Items & Age & $\begin{array}{l}\text { Mother's } \\
\text { education }\end{array}$ & $\begin{array}{l}\text { Number } \\
\text { of family }\end{array}$ & $\begin{array}{l}\text { Weight } \\
(\mathrm{Kg})\end{array}$ & $\begin{array}{l}\text { Baby's } \\
\text { homeland }\end{array}$ & $\begin{array}{l}\text { Diarrhea } \\
\text { duration }\end{array}$ & $\begin{array}{l}\text { No. of } \\
\text { motions/day }\end{array}$ & $\begin{array}{l}\text { character } \\
\text { of stool }\end{array}$ & Fever & Dehydration & $\begin{array}{l}\text { Type of } \\
\text { feeding }\end{array}$ & $\begin{array}{l}\text { Water } \\
\text { sources }\end{array}$ \\
\hline Age & 1 & & & & & & & & & & & \\
\hline $\begin{array}{l}\text { Mother's } \\
\text { education }\end{array}$ & -0.097 & 1 & & & & & & & & & & \\
\hline $\begin{array}{l}\text { Number of } \\
\text { family }\end{array}$ & 0.031 & $-0.186^{*}$ & 1 & & & & & & & & & \\
\hline $\begin{array}{l}\text { Weight } \\
(\mathrm{Kg})\end{array}$ & $0.581 * *$ & 0.036 & 0.105 & 1 & & & & & & & & \\
\hline $\begin{array}{l}\text { Baby's } \\
\text { homeland }\end{array}$ & 0.004 & -0.082 & -0.066 & -0.019 & 1 & & & & & & & \\
\hline $\begin{array}{l}\text { Diarrheal } \\
\text { duration }\end{array}$ & 0.032 & $-0.189^{*}$ & 0.058 & -0.095 & -0.018 & 1 & & & & & & \\
\hline $\begin{array}{l}\text { No. of } \\
\text { motions/day }\end{array}$ & -0.013 & 0.082 & 0.015 & -0.031 & 0.034 & 0.088 & 1 & & & & & \\
\hline $\begin{array}{l}\text { character of } \\
\text { stool }\end{array}$ & 0.335 ** & -0.094 & -0.033 & 0.161 & 0.093 & 0.117 & 0.041 & 1 & & & & \\
\hline Fever & 0.160 & 0.068 & 0.022 & 0.071 & -0.049 & 0.014 & -0.079 & 0.210 & 1 & & & \\
\hline Dehydration & -0.080 & 0.088 & 0.033 & 0.101 & -0.107 & -0.156 & -0.076 & -0.059 & $0.246^{* *}$ & 1 & & \\
\hline $\begin{array}{l}\text { Type of } \\
\text { feeding }\end{array}$ & $0.243 * *$ & 0.118 & -0.013 & $0.234^{* *}$ & 0.058 & 0.018 & 0.113 & $0.182^{*}$ & 0.042 & -0.127 & 1 & \\
\hline $\begin{array}{l}\text { Water } \\
\text { sources }\end{array}$ & 0.030 & -0.107 & -0.042 & -0.050 & $0.444^{* *}$ & 0.058 & 0.150 & 0.061 & $-0.166^{*}$ & $-0.246^{* *}$ & -0.027 & 1 \\
\hline
\end{tabular}

* Correlation is significant at the 0.05 level. ** Correlation is significant at the 0.01 level.

Table (6). Correlation coefficient between some studied variables and anthropometric measurements

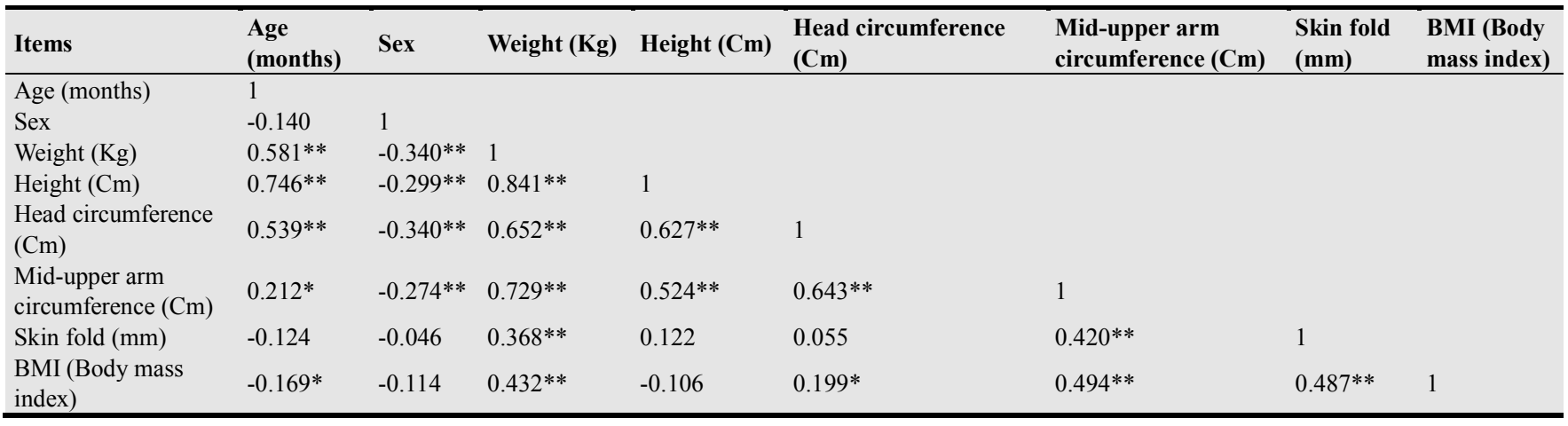

* Correlation is significant at the 0.05 level. ** Correlation is significant at the 0.01 level.

\section{Conclusion and Recommended}

These findings suggested that mothers educate, number of family members, sanitary water supply are crucial features in affection of children diarrhea disease.

The findings have important implications on policy for health intervention, and support the view that investing in female education may have substantial benefits on child health. Also, reducing diarrhea dangers involves providing better water sources and sanitation for the entire population and hygiene of the person caring of the child.

\section{References}

[1] WHO, World Health Organization, (2007). WHO child growth standards, head circumference-for- age, arm circumferencefor- age, triceps skinfold-for- age and subscapular skinfold- for- age. Methods and Development. ISBN 9789241547185, printed in China, Hong Kong, Special Administrative Region.

[2] Liu, L.; Johnson, HL.; Cousens, S.; Perin, J.; Scott, S.; Lawn, JE.; Rudan, I.; Campbell, H.; Cibulskis, R.; Li, M.; Mathers, C. and Black, RE. (2012).Global, regional, and national causes of child mortality: an updated systematic analysis for 2010 with time trends since 2000. Lancet, 379:2151-61.

[3] WHO, (2008) World Health Organization. WHO statistical Health Statistics. ISBN: 9789241563598 . Printed in France.

[4] Podewils L.J.; Mintz E.D.; Nataro J.P. and Parashar U.D. (2004). Acute, infectious diarrhea among children in developing countries. Semin Pediatr Infect Dis 15: 155-168.

[5] Gerald T. Keusch, O F and Alok B. (2001). Disease Control Priorities in Developing Countries, 371-388.

[6] Khaled Y. (2000).Morbidity and risk factor of diarrheal diseases among under five children in rural Upper Egypt. Journal of Tropical pediatrics, 46: 282-287. 
[7] El-Zanaty, Fatma and Way, Ann. 2009. Egypt Demographic and Health Survey 2008. Cairo, Egypt: Ministry of Health, ElZanaty and Associates, and Macro International (USAID and Unicef).

[8] Black, RE; Cousens, S; Johnson, HL; Lawn, JE; Rudan, I; Bassani, DG; Jha, P; Campbell, H.; Walker, CF.; Cibulskis, R.; Eisele, T.; Liu, L. and Mathers C. (2010).Global, regional, and national causes of child mortality in 2008: a systematic analysis. Lancet 375: 1969-1987.PubMed| Google Scholar

[9] Chen KT.; Fan SF.; Tang RB.; Huang YF.; Lee PI.; Chen, PY; Tang, CW. and Chen, HC. (2007). Hospital-based study of the economic burden associated with rotavirus diarrhea in Taiwan. Vaccine. May 22; 25 (21):4266-72. PubMed| Google Scholar

[10] Lohman TG, Roche AF, Martorel R (1988): edn. Human Kinetics Books: Champagne Illinois. Anthropometric standardization Reference Manual.

[11] Lee, R.D. and Nieman, D.C. (2003). Nutritional Assessment. 3rd Ed. Publisher, Wheatley, C.H. pp. 530.

[12] Jousilahti P, Madkour SM, Lambrechts T, Sherwin E. (1997). Diarrheal disease morbidity and home treatment practices in Egypt. Public Health;111(1):5-10. Google Scholar

[13] Barakat, A. and Halawa, E.F. (2013). Household costs of seeking outpatient care in Egyptian children with diarrhea: a cross-sectional study. Pan African Medical Journal. pp.14:42.
[14] Mohammed, S.; Tilahun, M. and Tamiru, D. (2013).Morbidity and Associated Factors of Diarrheal Diseases Among Under Five Children in Arba-Minch District, Southern Ethiopia. Science Journal of Public Health. 1(2): 102-106.

[15] Wierzba, FT; Abdel-Messih AI; Abu-Elyazeed R; Putnam SD; Kamal KA; Rozmajzl P; Ahmed SF; Abdel-Fatah KZ; Shaheen HI; Sanders J and Frenck R (2006). Clinic-Based surveillance for Bacterial and Rotavirus-Associated Diarrhea in Egyptian children. Am. J. Trop. Med. Hyg. 74 (1), pp. 148 -153 .

[16] Oadi, KO. and Kuitunen, M. (2005). Childhood diarrheal morbidity in the Accra Metropolitan Area, Ghana: Socioeconomic, environmental and behavioral risk determinants. J Health Pop. Dev. Countries: 33-46.

[17] Yilgwa, CS. and Okolo, S N. (2012). Prevalence of diarrhea disease and risk factors in Jos University Teaching Hospital, Nigeria. Ann Afr Med; 11: 217-21.

[18] Moore, SR; Lima, NL; Soares, AM; Ori, RB; Pinkerton, RC; Barret, LJ; Guerrant, RL and Lima, AA. (2010).Prolonged Episodes of Acute Diarrhea Reduce Growth and Increase Risk of Persistent Diarrhea in Children. Gastroenterology; 139:1156-1164.

[19] Jalan, J., and Ravallion, M. (2003). Does Piped Water Reduce Diarrhoea for Children in Rural India? Journal of Econometrics112: 153-73. 